\section{The Non-Proliferation Treaty - a requirement to reprocess?}

In the Windscale report Mr Justice Parker held that there was a case for THORP being large enough to reprocess foreign fuel as this would 'do something to relieve the pressure on non-nuclear-weapon states to develop their own facilities. It would also demonstrate that this country intends to honour at least the spirit, and as I think the letter, of its obligations under the NonProliferation 'Treaty (NPT)'

NPT came into force in 1970 and now has 103 states party to it. These include Japan, West Germany, Sweden and Switzerland but not Argentina, Brazil, France, India, Israel, Pakistan, People's Republic of China and South Africa.

Article I says amongst other things that each nuclear-weapon state party to the treaty undertakes not to transfer to anyone nuclear explosive devices, nor '. . to assist, encourage or induce any nonnuclear weapon state to manufacture or otherwise acquire nuclear weapons ...', and Article II is a similar commitment on behalf of non-nuclear weapon states not to make nuclear weapons nor to receive assistance in their manufacture. $\mathrm{Mr}$ Parker held that neither article could be taken to prevent the transfer of plutonium, only explosive devices. He also held that transferring plutonium could not be regarded as assisting proliferation because were it so the already considerable exports of plutonium by the UK and US to nonnuclear-weapon states must be regarded as contravening the NPT - which noone claimed at the time.

He further goes on to argue that since Articles III and IV mention peaceful uses of nuclear energy, both in terms of safeguards to prevent diversion to military purposes and in terms of reassurances that peaceful programmes are not meant to be interfered with, it must be assumed that those who framed the treaty recognised the non-nuclear-weapon states' interests in using fissionable material. What is more Article IV enjoins all parties to the NPT to facilitate 'the fullest possible exchange of equipment, materials and information for peaceful uses'. At the time the treaty was entered into, plotonium production by reprocessing was certainly envisaged. So, argues Parker 'I find it difficult to see how a party ... would be otherwise than in breach of the agreement if it . . refused to reprocess for another party'.

Further, Parker goes on to reject claims that if there was an obligation of this nature it could not be imposed if it in volved economic loss. 'The NPT is on its face a straightforward bargain', he writes. Loss would be a natural price to pay for restraint by non-nuclear weapon states.

0028-0836/78/0272-0303\$01.00

\section{$\mathrm{NFCE}$ - an exercise in proliferation}

INFCE, the International Nuclear Fuel Cycle Evaluation programme, was first heard of last April when President Carter, in the course of a major policy statement on nuclear proliferation, mentioned that discussions were being conducted with countries exporting or importing nuclear fuel and technology, with a view to developing an international viewpoint on how to keep the dangers of nuclear proliferation out of the nuclear fuel cycle.

Forty countries, IAEA, Euratom and $O E C D$ are now involved in INFCE, which had its first meeting last September. There has been strong support for the concept both from east and west; the only notable absentee is the People's Republic of China.

Eight separate study areas have been established:

- uranium supply

- enrichment

- security of supply

- reprocessing

- fast reactors

- spent fuel management

- waste management

- other fuel cycles.

The general philosophy is to explore ideas both concerning technical fixes and also establishing new frameworks for international cooperation.

Group 4, on reprocessing, is of particular interest at present; in it the UK and Japan are co-chairmen. There are two subgroups - one on reprocessing headed by Dr Walter Marshall (UKAEA), and one on thermal reactor recycling headed by $\mathrm{Dr} S$. Tamiya (Japan Power Co.)

At the present INFCE is much more of a technical evaluation exercise than an international negotiating forum and maybe as a result participants in it are optimistic that its deliberations will lead to a useful outcome. But, say some critics of the Windscale report, if INFCE is doing well and its discussions proceeding apace, why shouldn't BNFL wait a year or two rather than proceed with THORP now? The answer seems to be that participation in INFCE is seen as a means of assessing long-term options, not as a way of affecting short-term decisions.

Japan is a strong supporter of INFCE, and this is seen by many as a way to shake off the tight US controls on the export of enrichment and reprocessing technology.

One of the most serious problems for participants in INFCE is how they prevent a non-proliferation exercise from making proliferation easier. It is difficult to advise a non-nuclear-weapon state what it should do and what steer clear of without bringing the State that much nearer to having a nuclear weapons capability. Nor is it entirely possible to prevent such a forum from being a place where commercial expertise gets more widely disseminated than many would wish. So the price nuclear-weapon nations may have to pay for participating in INFCE may not be negligible, either politically or commercially.

\section{Swedish experts recommend nuclear energy - without reprocessing}

After more than a year's hard labour, the government-appointed Energy Commission has finished its work. Its final report, to be presented to parliament on 27 March, is already completed; and the tenor of its recommendations is clear. The majority of its members are in favour of between 10 and 13 nuclear reactors - the exact number has, according to informed sources, been left unspecified. This means a defeat for the Prime Minister's Centre Party, whose representatives on the Commission have been fighting to stop nuclear energy.

According to the same sources, the report says that reprocessing plants should not be built in Sweden for the time being. It also advises waiting for the results of the International Fuel Cycle Evaluation (INFCE) studies on the handling of spent fuel before making definite choices between different methods of final deposition and storage. It does, however, recommend continuing prospecting for uranium and preparations for some mining: although whether this should be in the fiercely-disputed Ranstad area, maintained by environmentalists to be untouchable, or in the far north, the report evidently does not make clear.

It is not at all sure what will happen after the report has been presented. Prime Minister Fälldin originally set up the Commission as a think tank which would recommend that nuclear power be stopped. This would have given him solid political backing for keeping the most important promise he made to the voters before his government came to power: of backtracking down the road to a nuclearenergy society. But now that the Commission has back-fired, Fälldin has said that he will treat its recommendations as one of a number; and has referred to the fact that the government does not always act according to the guidelines set down by advisory commissions. Whether he will in fact be able to withstand the enormous pressures that will be brought to bear on him by his two coalition partners - both pro-nuclear - is doubtful. He does of course hold the trump card of resignation, bringing the first non-socialist government in 44 years down with him; but such drastic action seems unlikely given his record of compromise - some would

Macmillan Journals Ltd 1978 